Article

\title{
Continuous-Flow Monolithic Silica Microreactors with Arenesulphonic Acid Groups: Structure-Catalytic Activity Relationships
}

\author{
Agnieszka Ciemięga ${ }^{1}$, Katarzyna Maresz ${ }^{1}$, Janusz J. Malinowski ${ }^{1}$ and \\ Julita Mrowiec-Białoń ${ }^{1,2, *}$ \\ 1 Institute of Chemical Engineering Polish Academy of Sciences, Bałtycka 5, 44-100 Gliwice, Poland; \\ akoreniuk@iich.gliwice.pl (A.C.); k.kisz@iich.gliwice.pl (K.M.); j.mal@iich.gliwice.pl (J.J.M.) \\ 2 Department of Chemical Engineering and Process Design, Silesian University of Technology, \\ Ks. M. Strzody 7, 44-100 Gliwice, Poland \\ * Correspondence: jmrowiec@polsl.pl; Tel.: +48-32-231-08-11
}

Academic Editors: Tian-Yi Ma, Jian-Rong (Jeff) Li and Cláudia Gomes Silva

Received: 11 July 2017; Accepted: 28 August 2017; Published: 30 August 2017

\begin{abstract}
The performance of monolithic silica microreactors activated with sulphonic acid groups and a packed bed reactor with Amberlyst 15 resin were compared in the esterification of acetic acid with n-butanol. The monolithic microreactors were made of single silica rods with complex pore architecture, differing in the size of mesopores, and in particular, flow-through macropores which significantly affected the flow characteristic of the continuous system. The highest ester productivity of $105.2 \mathrm{~mol} \cdot \mathrm{mol}_{\mathrm{H}}^{+-1} \cdot \mathrm{h}^{-1}$ was achieved in microreactor M1 with the largest porosity, characterized by a total pore volume of $4 \mathrm{~cm}^{3} \cdot \mathrm{g}^{-1}$, mesopores with $20 \mathrm{~nm}$ diameter, and large flow-through macropores $30-50 \mu \mathrm{m}$ in size. The strong impact of the permeability of the monoliths on a reaction kinetics was shown.
\end{abstract}

Keywords: silica monoliths; continuous-flow microreactors; acid centres; structure/catalytic activity relationships

\section{Introduction}

Synthesis of most fine and specialty chemical—particularly pharmaceuticals—is typically carried out in a liquid phase and batch operation, despite the fact that batch processes cause a number of problems, especially with scaling up and producing within homogeneous processing conditions [1]. Flow reactors have many advantages over batch reactors: continuous production, better process control, easier automation, and reduced operation costs. Moreover, continuous-flow heterogeneous catalytic processes offer higher selectivity, productivity, and elimination of costly catalyst separation from the reaction media [2,3]. The application of reactors involving solid catalysts in the form of either stationary or moving particles often leads to serious operational problems associated with mass and heat transfer limitations, excessive backpressure, thermal instabilities in stationary beds, etc. [4]. The replacement of a continuous flow reactor by monolithic microreactor-based technology appeared to be promising for the effective production of fine chemicals.

Continuous microreactors allow a miniaturization of the apparatus, which is of particular importance in fine chemical synthesis, and in the pharmaceutical and chemical industries [2]. A high surface to volume ratio of the rectors enables high concentrations of active sites per unit volume and provides better heat and mass transfer. Furthermore, precise control of the reaction temperature and residence time has a beneficial effect on the productivity and selectivity.

Microreactors can be made from a wide range of materials, and a variety of fabrication techniques have been proposed [5,6], often requiring special equipment and skills. Continuous-flow monolithic 
polymeric microreactors which have a well-defined system of flow-through pores show important advantages over packed bed reactors [7-9], but suffer from low thermal stability and a tendency to swell. More recently, however, it was shown [8] that highly cross-linked polymer monoliths do not suffer from the latter effects. In recent years, among the various types of microreactor, much attention has been paid to the reactors with reactive cores made of inorganic carriers-especially of monolithic silica. The silica-based microreactors were first proposed by the Montpellier group, and were made from a single monolith (MonoSil), the surface of which was functionalized with $-\mathrm{NH}_{2}$ or $-\mathrm{HSO}_{3}$ groups. Innovation of this approach stems from a unique hierarchical pore structure of the monolith in which flow-through macropores are connected to an extensive network of meso- and micropores present in the silica skeleton $[10,11]$. Owing to the unique hierarchical pore structure, the flow resistance could be reduced, permeability increased, and the accessibility of substrates to catalytic sites improved, giving an overall better performance compared to packed column [12]. The silica monoliths with hierarchical porosity were obtained by combining the phase separation method elaborated by Nakanishi $[13,14]$ with pseudomorphic synthesis $[15,16]$, to ensure an ordered mesoporous morphology of materials.

Hierarchically structuring both the porosity and the architecture of a material over a different length scale provides an opportunity to synthesize materials suitable for different applications, including catalysis and separation $[17,18]$. Recently, the synthesis strategies and catalytic performances exhibited by the hierarchically porous catalysts have been thoroughly reviewed [18].

Silica-based materials are extensively used in heterogeneous catalysis as an active site support due to the abundance of surface silanols, which allows the grafting of a wide variety of active species to meet specific catalytic demands [19] posed for the synthesis of fine chemicals [10]. Consequently, silica monoliths have been activated with organic groups [11,20], enzymes [21,22], or metal complexes [23], and successfully applied as active cores of continuous-flow microreactors.

In this work, we compare the performance of continuous-flow reactors fabricated using silica monoliths featuring different pore structure with that of the packed bed reactor filled with Amberlyst 15 resin. The reactors were tested in the esterification of acetic acid with n-butanol. The n-butyl acetate is the product of the model reaction which is of practical interest, being used as a solvent in the manufacturing of lacquer, artificial perfume, plastics, and safety glass, and also as a synthetic fruit flavouring in foods [24]. The silica monoliths were synthesized using four synthesis protocols to obtain carriers with significantly different structural parameters on both the meso- and macroscale. Subsequently, monoliths were functionalized with arenesulphonic acid groups in order to obtain monolithic microreactors with Brönsted acid centres. A strong impact of the macroporous structure on the flow characteristic of the microreactors was found, while the amount of anchored active groups correlated well with mesostructural properties (i.e., significant increase was recorded with increasing values of specific surface area). However, the structure of monoliths at macroscale decisively influenced the overall performance of the microreactors. The highest productivity was achieved in the monolith with the largest porosity, and not the largest surface area, which also offered the lowest pressure drop. The latter finding is also of major practical importance, and correlates very well with the observation most recently reported in [25].

\section{Results}

\subsection{Characterization of the Silica Monoliths}

Three silica monoliths designated as M1, M2, and M3 were fabricated using different synthesis protocols (see the Materials and Methods, Table 5). The monolith structure-in both the meso- and macropore scales-strongly depended on the composition of the reaction mixture and the synthesis process parameters thereof. The scanning electron microscopy images of the monoliths are displayed in Figure 1.

The images confirmed the presence of the bi-continuous, foam-like structure of the macropores in the monoliths. The characterization of the materials by low-temperature nitrogen adsorption and 
mercury porosimetry (Figure 2) revealed pore system architecture in different size scales. Structural properties of the materials are summarized in Table 1.

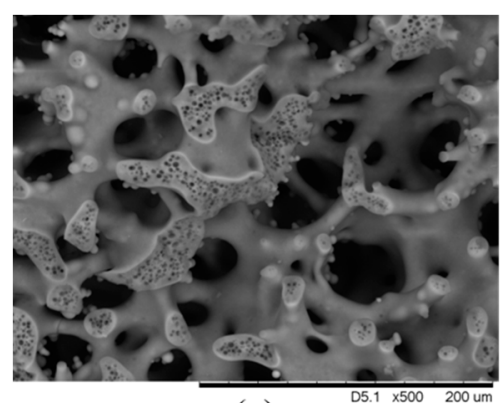

(a)

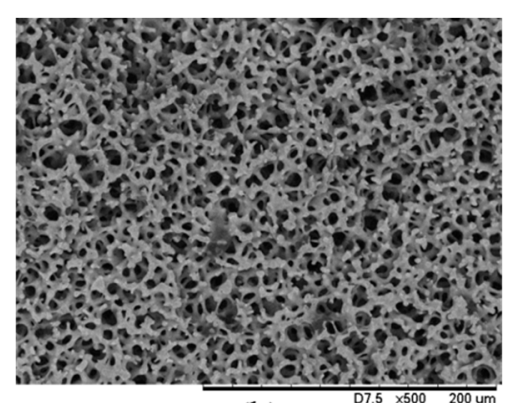

(b)

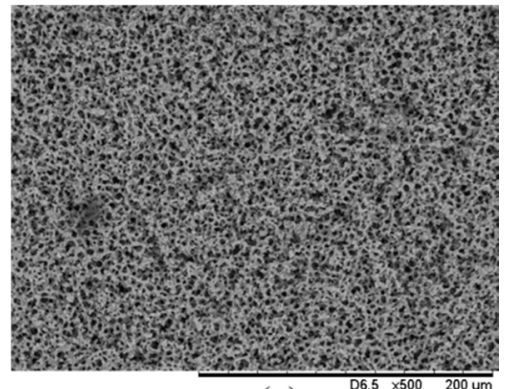

(c)

Figure 1. SEM images of (a) M1, (b) M2, and (c) M3 monoliths.

a

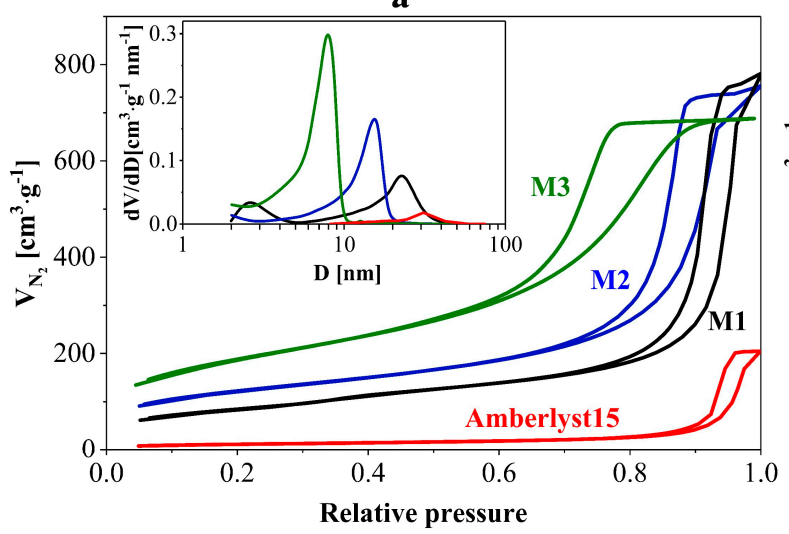

b

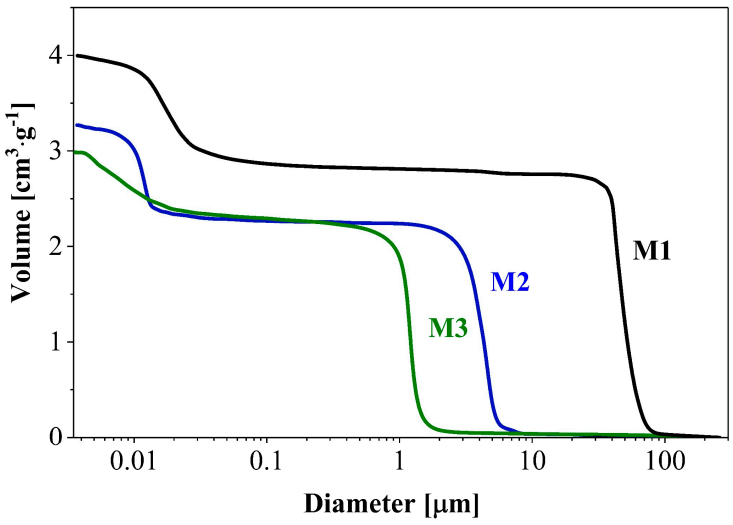

Figure 2. (a) $\mathrm{N}_{2}$ adsorption/desorption isotherms and pore size distribution in monoliths and Amberlyst 15; (b) Cumulative pore volume curves determined by mercury porosimetry.

Table 1. Structural and acidic properties of the materials.

\begin{tabular}{|c|c|c|c|c|c|c|c|}
\hline Sample & $\begin{array}{c}S_{\text {BET }} \\
\left(\mathrm{m}^{2} \cdot \mathrm{g}^{-1}\right)\end{array}$ & $\begin{array}{c}V p_{\text {mes }} \\
\left(\mathrm{cm}^{3} \cdot \mathrm{g}^{-1}\right)\end{array}$ & $\begin{array}{c}V_{T} \\
\left(\mathrm{~cm}^{3} \cdot \mathrm{g}^{-1}\right)\end{array}$ & $\begin{array}{l}D_{\text {mac }} \\
(\mu \mathrm{m})\end{array}$ & $\begin{array}{c}D_{\text {mes }} 1 \\
(\mathrm{~nm})\end{array}$ & $\begin{array}{c}\mathrm{H}^{+} \\
\left(\mathrm{mmol}^{\prime} \mathrm{g}^{-1}\right)\end{array}$ & $\underset{4}{A_{200} / A_{150}}$ \\
\hline M1 & $\begin{array}{c}328 \\
(245)^{2}\end{array}$ & $\begin{array}{c}1.15 \\
(0.91)\end{array}$ & $\begin{array}{c}4 \\
(3.72)\end{array}$ & $\begin{array}{c}30-50 \\
(30-50)\end{array}$ & $\begin{array}{c}2.5 / 20 \\
(20)\end{array}$ & 0.65 & 0.9 \\
\hline M2 & $\begin{array}{c}413 \\
(316)\end{array}$ & $\begin{array}{c}1.12 \\
(0.91)\end{array}$ & $\begin{array}{l}3.27 \\
3.01\end{array}$ & $\begin{array}{l}4-6 \\
4-6\end{array}$ & $\begin{array}{c}15 \\
(14.9)\end{array}$ & 0.85 & 0.9 \\
\hline M3 & $\begin{array}{c}575 \\
(427)\end{array}$ & $\begin{array}{c}1.04 \\
(0.74)\end{array}$ & $\begin{array}{l}2.98 \\
2.65\end{array}$ & $\begin{array}{l}1.3 \\
1.3\end{array}$ & $\begin{array}{c}8.7 \\
(7.9)\end{array}$ & 0.97 & 0.8 \\
\hline Amberlyst & 40 & 0.33 & - & - & 31 & $4.7^{3}$ & $\mathrm{n} / \mathrm{a}$ \\
\hline
\end{tabular}

${ }^{1}$ a maximum of the pore size distribution curve by $\mathrm{BJH}^{2}{ }^{2}$ in parentheses, texture parameters after functionalization with acidic groups; ${ }^{3}$ manufacturer's data; ${ }^{4}$ relative strength of Brönsted acid sites (BAS).

Monolith M1 synthesized in the presence of surfactant and hydrothermally treated in ammonia solution at $90{ }^{\circ} \mathrm{C}$ featured bimodal mesopore structure (small mesopores with diameters of $2-4 \mathrm{~nm}$ and larger ones in the size of 10-35 nm) and large macropores with diameters in the range of 30-50 $\mu \mathrm{m}$. The bimodal mesopore structure originated from the presence of a micelle-forming surfactant. Monolith M2 hydrothermally treated in ammonia solution at $80^{\circ} \mathrm{C}$ had a uniform mesopore structure in the range of $10-20 \mathrm{~nm}$ and macropores with diameters ca. $5 \mu \mathrm{m}$. As reported earlier [26,27], the size 
of the macropores decreased with the increase in the value of polyethylene glycol (PEG)/Si ratio (Table 1, Figure 2). In turn, the use of a higher concentration of nitric acid in the synthesis of monolith (sample M3) resulted in the formation of smaller macropores with a small effect on the volume of the macropores. This phenomenon was interpreted as an effect of a faster hydrolysis and slower condensation of siliceous species in acidic conditions [28]. The pore structure in the nanometer range was tailored by a post-gelation treatment of the silica monoliths in ammonia solution, as well as an application of a cationic surfactant. The total pore volume $\left(\mathrm{V}_{\mathrm{T}}\right)$ of the monoliths was very large (in the range of $3-4 \mathrm{~cm}^{3} \cdot \mathrm{g}^{-1}$ ), while the mesopore volume (Vpmes) was comparable (ca. $1.1 \mathrm{~cm}^{3} \cdot \mathrm{g}^{-1}$ ). Monolith M3 was characterized by the largest specific surface area $\left(575 \mathrm{~m}^{2} \cdot \mathrm{g}^{-1}\right)$, which is associated with the presence of small mesopores. Monoliths M1 and M2 also differed in the structure of the silica skeleton. Monolith M2 was characterized by a uniform wall thickness (about $5 \mu \mathrm{m}$ ), while in monolith M1 there were visible structural elements of different thicknesses ranging from a few to tens of micrometers. Ion-exchange resin Amberlyst 15 exhibited large mesopores (cf. inset to Figure 2) of volume ca. $0.3 \mathrm{~cm}^{3} \cdot \mathrm{g}^{-1}$ (i.e., four times smaller than in the synthesized monoliths).

Thermal stability of the catalyst is of primary importance-particularly when it contains organic groups. The thermal stability of arenesulphonic acid groups attached to the monoliths' surface and their amount were determined by thermogravimetric method. The results are shown in Figure 3 and in Table 1. All samples were stable up to $350{ }^{\circ} \mathrm{C}$. The sharp weight loss below $120^{\circ} \mathrm{C}$ corresponds to physisorbed water. The amount of incorporated acidic groups was calculated from mass loss in the range of $300-700{ }^{\circ} \mathrm{C}$, resulting from thermal decomposition of functional groups. A strong relationship between specific surface area of silica skeleton and chemically bonded acidic groups was observed. Monolith M3 with the largest specific surface area had the highest amount of anchored acidic groups (Table 1), which correlates very well with the content of hydroxyls employed to attach functional groups [29].

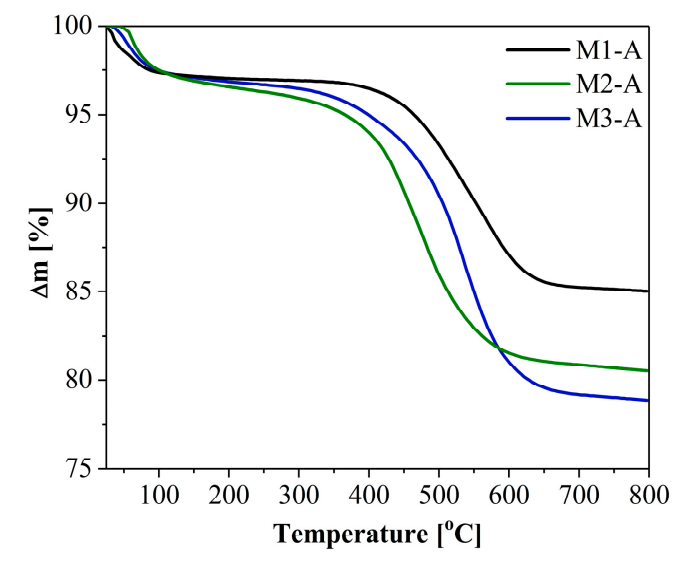

Figure 3. Thermogravimetric (TG) curves of the functionalized silica monoliths.

The identification of acid sites and their strength were studied using pyridine (Py) adsorption combined with Fourier transform infrared (FTIR) studies. The spectra recorded before and after the adsorption and desorption at different temperatures for M1 are depicted in Figure 4. The bands at 1488,1542 , and $1634 \mathrm{~cm}^{-1}$ derive from pyridinium ions bonded to Brönsted acid sites (BAS). The fact that the characteristic bands still remained after evacuation at $150{ }^{\circ} \mathrm{C}$ and $200{ }^{\circ} \mathrm{C}$ confirmed the presence of strong BAS. The band at $1443 \mathrm{~cm}^{-1}$-visible after adsorption-disappeared at $150{ }^{\circ} \mathrm{C}$, and it corresponds to hydrogen-bonded pyridine. The relative acid strength was calculated based on the intensity of the adsorption band centered at $1542 \mathrm{~cm}^{-1}$. The ratio of the integrated area of the peaks obtained at $200{ }^{\circ} \mathrm{C}$ and $150{ }^{\circ} \mathrm{C}$ represents the fraction of acid sites still containing chemisorbed Py after evaluation at these temperatures and reduced pressure. The data in Table 1 confirmed that strength of 
BAS is comparable for all the samples. The value of $A_{200} / A_{150}$ nearly close to unity is characteristic of strong acid sites [30,31].

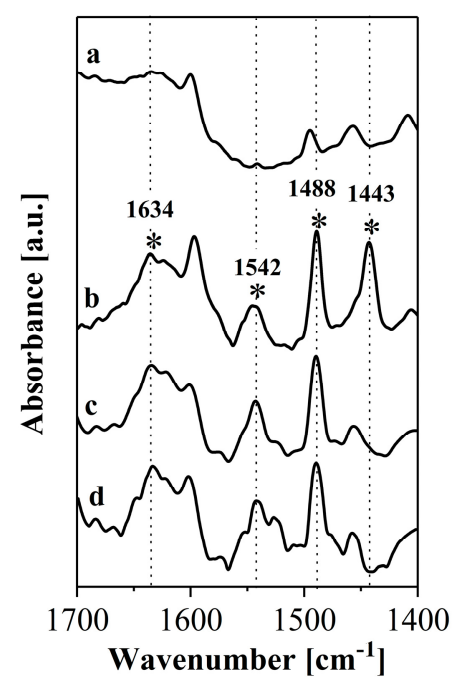

Figure 4. Fourier transform infrared (FTIR) spectra of M1-A: (a) before and (b) after pyridine adsorption, and after evacuation at (c) $150{ }^{\circ} \mathrm{C}$ and (d) $200^{\circ} \mathrm{C}$.

The relationship between the pressure drop and the flow rate is of practical significance, providing additional knowledge which is useful in assessing process economics. Thus, the pressure drop was measured for all monolithic microreactors and the packed bed reactor equipped with the Amberlyst 15 resin. It was found that it strongly depended on the size of the flow-through macropores, and a significant increase in pressure was recorded in the order M1 $<\mathrm{M} 2<\mathrm{M} 3$ (Figure 5), which correlates very well with the decreasing pore size. The reduction in the size of the flow-through macropores (from ca. $50 \mu \mathrm{m}$ to $1 \mu \mathrm{m}$ ) resulted in the increase in pressure drop of a few orders of magnitude. In the packed bed reactor, the pressure drop was twice as large as that recorded in the M1 microreactor.

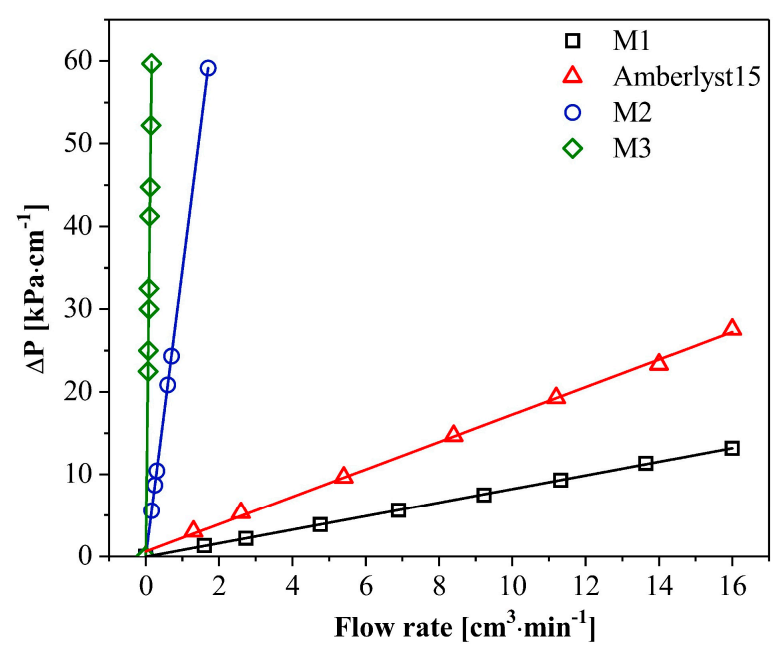

Figure 5. Pressure drop vs. flow rate in microreactors and the packed bed reactor with Amberlyst 15.

The permeability of the monoliths and the packed bed reactor (Amberlyst) was calculated using Darcy equation [25], and the results obtained are shown in Table 2. The permeability coefficient was three orders of magnitude lower in M3 than in M1, in perfect agreement with the smaller size of macropores in that material. 
Table 2. Permeability of silica monoliths and Amberlyst 15.

\begin{tabular}{cc}
\hline Sample & Permeability $\mathbf{K} \cdot \mathbf{1 0}^{\mathbf{1 2}}\left(\mathbf{m}^{\mathbf{2}}\right)$ \\
\hline M1 & 11.3 \\
M2 & 0.27 \\
M3 & 0.025 \\
Amberlyst 15 & 5.4 \\
\hline
\end{tabular}

\subsection{Catalytic Performance}

The performance of continuous-flow monolithic microreactors and the packed bed reactor with Amberlyst 15 resin was compared in the esterification of acetic acid with n-butanol. Catalytic tests were performed for at least $6 \mathrm{~h}$, at a flow rate of $0.06 \mathrm{~cm}^{3} \cdot \mathrm{min}^{-1}$ (representative graph for M1-A is shown in Figure 6). The flow rate was selected to achieve conversion smaller than $50 \%$ to discriminate efficacy of different structure.

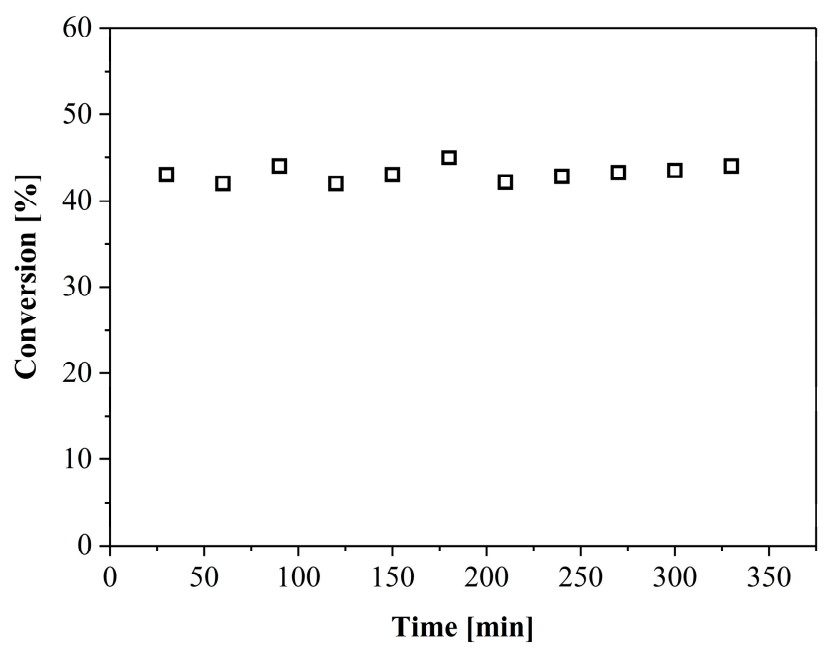

Figure 6. Conversion vs. time in the M1-A microreactor.

One of the key factors in continuous flow reactors' performance is the residence time $(\tau)$ of a reactant molecule in the active zone. According to Sachse et al. [32], for the monolithic reactor $\tau$ may be determined from the following expression:

$$
\tau=\mathrm{xmV}_{\mathrm{T}} / \mathrm{F},
$$

where $\mathrm{x}$ is monolith length, $\mathrm{m}$ is a weight per $\mathrm{cm}\left(\mathrm{g} \cdot \mathrm{cm}^{-1}\right)$, and $\mathrm{F}$ is the flow rate $\left(\mathrm{cm}^{3} \cdot \mathrm{min}^{-1}\right)$.

Thus, the more open the structure (as found in M1), the longer the residence time (Table 2) for the same flow rate.

The productivity—expressed in mol of product formed per kg of catalyst per $\mathrm{h}$-was calculated from conversion (Conv) and initial concentration of reactant $\left(\mathrm{C}_{0}\right)$ using the equation:

$$
\mathrm{P}=\mathrm{C}_{0} \operatorname{Conv} \mathrm{V}_{\mathrm{T}} / \tau \text {. }
$$

The value of productivity calculated for all microreactors was similar and of ca. $68 \mathrm{~mol} \cdot \mathrm{kg}_{\mathrm{cat}}{ }^{-1} \cdot \mathrm{h}^{-1}$ (Table 3). However, if the productivity was related to the concentration of active centers (mmol of product per mmol of active centers per hour), the M1-A microreactor showed superior performance. This can be ascribed to: (i) enhanced mass transfer from a core of reactants to the skeleton's surface, and (ii) easier access of reactants to active sites embedded in much larger mesopores of M1-A than in M2-A and M3-A. On the other hand, a greater density of active sites in M2-A and M3-A enabled compensation 
for the higher activity of the M1-A catalytic sites. However, M1 monoliths revealed the largest permeability of liquids (Table 2), and this bears directly on pressure drop and hence power/energy input and also safety. Thus, bearing in mind all factors, we consider the M1-A microreactor as the most effective solution.

Table 3. Results from catalytic experiments.

\begin{tabular}{|c|c|c|c|c|}
\hline Sample & $\begin{array}{c}\text { Conversion } \\
(\%)\end{array}$ & $\begin{array}{c}\tau \\
(\min )\end{array}$ & $\begin{array}{c}\text { Productivity } \\
\left(\mathrm{mol}^{\circ} \cdot \mathrm{kg}_{\text {cat }}-1 \cdot \mathrm{h}^{-1}\right)\end{array}$ & $\begin{array}{c}\text { Productivity } \\
\left(\mathrm{mol}^{\prime} \mathrm{mol}_{\mathrm{H}}^{+-1} \cdot \mathrm{h}^{-1}\right)\end{array}$ \\
\hline M1-A & 42 & 10 & 68.4 & 105.2 \\
\hline M2-A & 41 & 8 & 67.2 & 79.2 \\
\hline M3-A & 42 & 7.5 & 68.4 & 70.8 \\
\hline Amberlyst 15 & 38 & 4.2 & 61.8 & 13.2 \\
\hline
\end{tabular}

The productivity in the reactor packed with Amberlyst 15 was about $86 \%$ of the M1-A microreactor, despite a similar conversion as in M-type reactors. It is important to emphasize that in the case of monolithic microreactors, higher conversions can be achieved by increasing the length of the microreactor or by applying numbering-up approach [5]. For example, by connecting two the M1-A reactors in series, a conversion of $62 \%$ was reached (data not shown here).

The M1-A performance also most favourably compares with other studies reported previously (Table 4).

Table 4. Comparison of acetic acid esterification with n-butanol in flow (entries 1-2) and batch (entries 3-5) reactors.

\begin{tabular}{|c|c|c|c|c|c|c|}
\hline Entry & Catalyst & $\begin{array}{c}\text { Conversion } \\
(\%)\end{array}$ & $\begin{array}{c}\text { Productivity } \\
\left(\mathrm{mol} \cdot \mathrm{kg}_{\mathrm{cat}}{ }^{-1} \cdot \mathrm{h}^{-1}\right)\end{array}$ & $\begin{array}{l}\text { Temp. } \\
\left({ }^{\circ} \mathrm{C}\right)\end{array}$ & $\begin{array}{l}\text { Time } \\
(\mathrm{min})\end{array}$ & Ref. \\
\hline 1 & M1-A & 42 & 68.4 & 75 & $10^{2}$ & This work \\
\hline 2 & Amberlyst $15^{1}$ & 70 & 30 & 80 & $10^{2}$ & [33] \\
\hline 3 & Al-MCM-41 & 50 & 29.4 & 150 & 360 & [34] \\
\hline 4 & H-USY-20 & 35 & 13.8 & 75 & 360 & [35] \\
\hline 5 & Smopex-101 & 65 & 37.8 & 75 & 360 & [35] \\
\hline
\end{tabular}

\section{Materials and Methods}

\subsection{Monoliths Synthesis and Activation}

Three silica monoliths (M1-M3) in the form of rods with diameter of $4.5 \mathrm{~mm}$ were prepared using Nakanishi approach [13,14] with minor modifications [26,27]. In brief, polyethylene glycol (PEG 35000, Sigma-Aldrich, St. Louis, MO, USA) was dissolved in aqueous $\mathrm{HNO}_{3}$ (Avantor, 65\%, Gliwice, Poland), after which tetraethoxysilane (TEOS, ABCR, 99\%, Karlsruhe, Germany) was added slowly to the PEG solution in an ice bath followed by the addition of cetyltrimethylammonium bromide (CTAB, Sigma-Aldrich) (sample M1). Details of the composition of the reagents are given in Table 5.

After treatment with ammonia (Avantor, 25\%), the samples were washed with deionized water and dried for 3 days at $40{ }^{\circ} \mathrm{C}$. Finally, the samples were calcined at $550{ }^{\circ} \mathrm{C}$ for $8 \mathrm{~h}\left(\operatorname{ramp~} 1^{\circ} \mathrm{C} \cdot \mathrm{min}^{-1}\right)$.

Single silica rods (ca. $4 \mathrm{~cm}$ long) were embedded into heat-shrinkable Teflon tubes, equipped with connectors to obtain a microreactor suitable for a continuous operation. Subsequently, silica monoliths were functionalized under flow $\left(48 \mathrm{~h}, 60^{\circ} \mathrm{C}\right)$ with arenesulphonic acid groups using solution of 2-(4-chlorosulfonylphenyl)ethyltrimethoxysilane (CSPTMS; 50 wt \% solution in $\mathrm{CH}_{2} \mathrm{Cl}_{2}, \mathrm{ABCR}$ ) dissolved in anhydrous ethanol. The functionalized monoliths were designated as M1-A, M2-A, and M3-A. The nominal content of organic groups was $1.5 \mathrm{mmol} \cdot \mathrm{g}^{-1}$. After activation, the material was washed extensively with ethanol (Avantor, 99.8\%) to remove a non-bonding precursor. 
Table 5. Composition of reagents for monolith synthesis and conditions during ammonia aqueous solution treatment of monoliths prior to drying. PEG: polyethylene glycol.

\begin{tabular}{|c|c|c|c|c|c|c|c|c|c|}
\hline \multirow[b]{2}{*}{ Sample } & \multirow{2}{*}{$\begin{array}{r}\text { TEOS } \\
\left(\mathrm{cm}^{3}\right)\end{array}$} & \multirow{2}{*}{$\begin{array}{c}\text { PEG } \\
\text { (g) }\end{array}$} & \multirow{2}{*}{$\begin{array}{l}\mathrm{H}_{2} \mathrm{O} \\
\left(\mathrm{cm}^{3}\right)\end{array}$} & \multirow{2}{*}{$\begin{array}{c}\mathrm{HNO}_{3} \\
\left(\mathrm{~cm}^{3}\right)\end{array}$} & \multirow{2}{*}{$\begin{array}{c}\text { CTAB } \\
\text { (g) }\end{array}$} & \multirow{2}{*}{$\begin{array}{l}\text { Aging } \\
\text { (Days) }\end{array}$} & \multicolumn{3}{|c|}{ Ammonia Treatment } \\
\hline & & & & & & & $\begin{array}{l}\text { Conc. } \\
\text { (M) }\end{array}$ & $\begin{array}{c}\text { Time } \\
\text { (h) }\end{array}$ & $\begin{array}{l}\text { Temp. } \\
\left({ }^{\circ} \mathrm{C}\right)\end{array}$ \\
\hline M1 & 26.1 & 2.73 & 30.10 & 2.18 & 1.2 & 7 & 1 & 8 & 90 \\
\hline M2 & 26.1 & 3.31 & 31.44 & 2.04 & 0 & 3 & 1 & 24 & 80 \\
\hline M3 & 26.1 & 3.32 & 32.05 & 2.39 & 0 & 3 & 0.1 & 20 & 40 \\
\hline
\end{tabular}

\subsection{Characterization of Materials}

The mesoporous textural properties of the materials were determined from low-temperature nitrogen sorption (Micromeritics ASAP 2020, Norcross, GA, USA). The samples were outgassed in a vacuum for $24 \mathrm{~h}$ at $200{ }^{\circ} \mathrm{C}$ prior to the analysis. The specific surface area $\mathrm{S}_{\mathrm{BET}}$ was determined using a standard BET method [36]. The mesopore volume and pore size distribution were calculated from the desorption branch of the isotherm using BJH model [37]. The macroporous network of pores in the silica monoliths was investigated by mercury porosimetry (PoreMaster 60, Quantachrome, Boynton Beach, FL, USA) and by scanning electron microscopy (TM 30000, Hitachi, Tokyo, Japan). Thermal properties and the amount of acidic groups attached to the silica carrier were studied by thermogravimetric analysis (STAR 853, Mettler Toledo, Greifensee, Switzerland). The type and strength of acid centres were determined using pyridine as a probe molecule and a FTIR-DRIFT spectrometer (NICOLET 6700, Thermo Fisher Scientific, Waltham, MA, USA) equipped with high temperature/vacuum chamber with ZnSe windows.

\subsection{Catalytic Tests}

The catalytic tests were performed in the esterification of acetic acid (Avantor, p.a) with n-butanol (Avantor, p.a) in a continuous-flow monolithic microreactor fabricated using monoliths M1-M3 and a packed bed reactor filled with Amberlyst 15 resin (particle size of $0.7 \pm 0.1 \mathrm{~mm}$, Sigma-Aldrich). The esterification process was examined for the molar ratio of substrates $1: 1$ and at $75^{\circ} \mathrm{C}$ using flow rate of $0.06 \mathrm{~cm}^{3} \cdot \mathrm{min}^{-1}$. The catalytic tests were carried out for $6 \mathrm{~h}$. The progress of the reaction was monitored by gas chromatography (Agilent 7890 A; FID detector; HP-5 column, Agilent Technologies, Palo Alto, CA, USA).

\section{Conclusions}

The presented studies clearly showed that the performance of the continuous-flow monolithic microreactors strongly depended on the silica structure both on meso- and macro-scale. It was shown that slight changes in the synthesis procedure strongly affected the structure of monoliths, which translated directly into a significant effect of their flow characteristic. The extremely high pressure drop was recorded when decreasing the size of the macropores from ca. $50 \mu \mathrm{m}$ to $1.3 \mu \mathrm{m}$. Furthermore, smaller mesopores were detected in monoliths with small macropores, which resulted in a considerable increase (ca. $60 \%$ of specific surface area). Consequently, a larger concentration of arenesulphonic groups (up to 50\%) was identified in these monoliths. However, the microreactors with much larger macroporosity appeared to be the most effective; i.e., they were characterized by a lower pressure drop and higher productivity in the esterification process despite the smaller concentration of active groups. The studied microreactors have strong Brönsted acid sites and they can operate up to $300{ }^{\circ} \mathrm{C}$. Moreover, the performance of the best microreactor appeared to be significantly better than that found for the reactor packed with Amberlyst 15.

Acknowledgments: This work was financed by the National Science Centre Project no DEC-2014/15/N/ST8/03171. 
Author Contributions: A.C., K.M. and J.M.-B. conceived and designed the experiments, analysed the data and wrote the paper; J.J.M. wrote part of the manuscript.

Conflicts of Interest: The authors declare no conflict of interest.

\section{References}

1. Plumb, K. Continuous processing in the pharmaceutical industry-Changing the mind set. Chem. Eng. Res. Des. 2005, 83, 730-738. [CrossRef]

2. Malet-Sanz, L.; Susanne, F. Continuous flow synthesis. A pharma perspective. J. Med. Chem. 2012, 55, 4062-4098. [CrossRef] [PubMed]

3. Teoh, S.K.; Rathi, C.; Sharratt, P. Practical assessment methodology for converting fine chemicals processes from batch to continuous. Org. Process Res. Dev. 2016, 20, 414-431. [CrossRef]

4. Stankiewicz, A. Process intensification in in-line monolithic reactor. Chem. Eng. Sci. 2001, 56, 359-364. [CrossRef]

5. Ehrfeld, W.; Hessel, V.; Lowe, H. Microreactors: New Technology for Modern Chemistry; Willey-VCH: Weinheim, Germany, 2000.

6. Wirth, T. Microreactors in Organic Chemistry and Catalysis, 2nd ed.; Willey-VCH: Weinheim, Germany, 2013.

7. Peterson, D.S.; Rohr, T.; Svec, F.; Frechet, J.M.J. Enzymatic microreactor-on-a-chip: Protein mappingusing trypsin immobilized on porous polymer monoliths molded in channels of microfluidic devices. Anal. Chem. 2002, 74, 4081-4088. [CrossRef] [PubMed]

8. Poupart, P.; Le Droumaguet, B.; Guerrouache, M.; Carbonnier, B. Copper nanoparticles supported on permeable monolith with carboxylic acid surface functinality: Stability and catalytic properties under reductive conditions. Mater. Chem. Phys. 2015, 163, 446-452. [CrossRef]

9. Khalil, A.M.; Georgiadou, V.; Guerrouache, M.; Mahouche-Chergui, S.; Dendrinou-Samara, C.; Chehimi, M.M.; Carbonnier, B. Gold-decorated polymeric monoliths: In-situ vs. ex-situ immobilization strategies and flow through catalytic applications towards nitrophenol reduction. Polymer 2015, 77, $218-226$. [CrossRef]

10. El Kadib, A.; Chimenton, R.; Sachse, A.; Fajula, F.; Galarneau, A.; Coq, B. Functionalized inorganic monolithic microreactors for high productivity in fine chemicals catalytic synthesis. Angew. Chem. Int. Ed. 2009, 48, 4969-4972. [CrossRef] [PubMed]

11. Sachse, A.; Galarneau, A.; Fajula, F.; Di Renzo, F.; Creux, P.; Coq, B. Functional silica monoliths with hierarchical uniform porosity as continuous flow catalytic reactors. Microporous Mesoporous Mater. 2011, 140, 58-68. [CrossRef]

12. Siouffi, A.M. Silica gel-based monoliths prepared by the sol-gel method: Facts and figures. J. Chromatogr. A 2003, 1000, 801-818. [CrossRef]

13. Nakanishi, K.; Minakuchi, H.; Soga, N.; Tanaka, N. Structure design of double-pore silica and its application to HPLC. J. Sol. Gel Sci. Technol. 1998, 13, 163-169. [CrossRef]

14. Nakanishi, K.; Kobayashi, Y.; Amatani, T.; Hirao, K.; Kodaira, T. Spontaneous formation of hierarchical macro-mesoporous ethane-silica monolith. Chem. Mater. 2004, 16, 3652-3658. [CrossRef]

15. Galarneau, A.; Iapichella, J.; Bonhomme, K.; Di Renzo, F.; Kooyman, P.; Terasaki, O.; Fajula, F. Controlling the morphology of mesostructured silicas by pseudomorphic transformation: A route towards applications. Adv. Funct. Mater. 2006, 16, 1657-1667. [CrossRef]

16. Martin, T.; Galarneau, A.; Di Renzo, F.; Fajula, F.; Plee, D. Morphological control of MCM-41 by pseudomorphic synthesis. Angew. Chem. Int. Ed. 2002, 41, 2590-2592. [CrossRef]

17. Na, K.; Jo, C.; Kim, J.; Cho, K.; Jung, J.; Seo, Y.; Messinger, R.J.; Chmelka, B.F.; Ryoo, R. Directing zeolite structures into hierarchically nanoporous architectures. Science 2011, 333, 328-332. [CrossRef] [PubMed]

18. Li, X.Y.; Sun, M.H.; Rooke, J.C.; Chen, L.H.; Su, B.L. Synthesis and applications of hierarchically porous catalysts. Chin. J. Catal. 2013, 34, 22-47. [CrossRef]

19. Hoffmann, F.; Cornelius, M.; Morell, J.; Froba, M. Silica-based mesoporous organic-inorganic hybrid materials. Angew. Chem. Int. Ed. 2006, 45, 3216-3251. [CrossRef] [PubMed]

20. Koreniuk, A.; Maresz, K.; Odrozek, K.; Jarzębski, A.B.; Mrowiec-Białoń, J. Highly effective continuous-flow monolithic silica microreactors for acid catalyzed processes. Appl. Catal. A 2015, 489, 203-208. [CrossRef] 
21. Szymańska, K.; Pudło, W.; Mrowiec-Białoń, J.; Czardybon, A.; Kocurek, J.; Jarzębski, A.B. Immobilization of invertase on silica monoliths with hierarchical pore structure to obtain continuous flow enzymatic microreactors of high performance. Microporous Mesoporous Mater. 2013, 170, 75-82. [CrossRef]

22. Kawakami, K.; Sera, Y.; Sakai, S.; Ono, T.; Ijima, H. Development and characterization of a silica monolith immobilized enzyme micro-bioreactor. Ind. Eng. Chem. Res. 2005, 44, 236-240. [CrossRef]

23. Koreniuk, A.; Maresz, K.; Mrowiec-Białoń, J. Supported zirconium-based continuous-flow microreactor for effective Meerwein-Ponndorf-Verley reduction of cyclohexanone. Catal. Commun. 2015, 64, 48-51. [CrossRef]

24. Cheung, H.; Tanke, R.S.; Torrence, G.P. Ullman's Encyclopedia of Industrial Chemistry; Willey-VCH: Weinheim, Germany, 2012.

25. Szymańska, K.; Odrozek, K.; Zniszczoł, A.; Pudło, W.; Jarzębski, A.B. A novel hierarchically structured siliceous packing to boost the performance of rotating bed enzymatic reactors. Chem. Eng. J. 2017, 315, 18-24. [CrossRef]

26. Smått, J.H.; Schunk, S.; Linden, M. Versatile double-templating synthesis route to silica monoliths exhibiting a multimodal hierarchical porosity. Chem. Mater. 2003, 15, 2354-2361. [CrossRef]

27. Pudło, W.; Gawlik, W.; Mrowiec-Białoń, J.; Buczek, T.; Malinowski, J.J.; Jarzębski, A.B. Materials with multimodal hierarchical porosity. Inzynieria Chemiczna i Procesowa 2006, 27, 177-185.

28. Szymańska, K.; Pietrowska, M.; Kocurek, J.; Maresz, K.; Koreniuk, A.; Mrowiec-Białoń, J.; Widłak, P.; Magner, E.; Jarzębski, A. Low back-pressure hierarchically structured multichannel microfluidic bioreactors for rapid protein digestion-Proof of concept. Chem. Eng. J. 2016, 287, 148-154. [CrossRef]

29. Mrowiec-Białon, J. Determination of hydroxyls density in the silica-mesostructured cellular foams by thermogravimetry. Thermochim. Acta 2006, 443, 49-52. [CrossRef]

30. Stawicka, K.; Diaz-Alvarez, A.E.; Calvino-Casilda, V.; Trejda, M.; Banares, M.A.; Ziolek, M. The role of Brönsted and Lewis acid sites in acetalization of glycerol over modified mesoporous cellular foams. J. Phys. Chem. C 2016, 120, 16699-16711. [CrossRef]

31. Datka, J.; Turek, A.M.; Jehng, J.M.; Wachs, I.E. Acidic properties of supported niobium oxide catalysts-An infrared-spectroscopy investigation. J. Catal. 1992, 135, 186-199. [CrossRef]

32. Sachse, A.; Hulea, V.; Finiels, A.; Coq, B.; Fajula, F.; Galarneau, A. Alumina-grafted macro-/mesoporous silica monoliths as continuous flow microreactors for the Diels-Alder reaction. J. Catal. 2012, 287, 62-67. [CrossRef]

33. Kulkarni, A.A.; Zeyer, K.P.; Jacobs, T.; Kienle, A. Miniaturized systems for homogeneously and heterogeneously catalyzed liquid-phase esterification reaction. Ind. Eng. Chem. Res. 2007, 46, 5271-5277. [CrossRef]

34. Jermy, B.R.; Pandurangan, A. A highly efficient catalyst for the esterification of acetic acid using n-butyl alcohol. J. Mol. Catal. A Chem. 2005, 237, 146-154. [CrossRef]

35. Peters, N.E.; Benes, N.E.; Holmen, A.; Keurentjes, J.T.F. Comparison of commercial solid acid catalysts for the esterification of acetic acid with butanol. Appl. Catal. A 2006, 297, 182-188. [CrossRef]

36. Brunauer, S.; Emmett, P.H.; Teller, E. Adsorption of gases in multimolecular layers. J. Am. Chem. Soc. 1938, 60, 309-319. [CrossRef]

37. Barrett, E.; Joyner, L.; Halenda, P. The determination of pore volume and area distributions in porous substances. Computations from nitrogen isotherms. J. Am. Chem. Soc. 1951, 73, 373-380. [CrossRef]

(C) 2017 by the authors. Licensee MDPI, Basel, Switzerland. This article is an open access article distributed under the terms and conditions of the Creative Commons Attribution (CC BY) license (http://creativecommons.org/licenses/by/4.0/). 